\title{
Protecting working-age people with disabilities: experiences of four industrialized nations
}

\author{
Richard V. Burkhauser ${ }^{1,2,3,5,7} \cdot$ Mary C. Daly ${ }^{4,5,6} \cdot$ Nicolas R. Ziebarth $^{1,5,7}$
}

Accepted: 11 August 2016 / Published online: 17 October 2016

(C) The Author(s) 2016. This article is available at SpringerLink with Open Access.

\begin{abstract}
Although industrialized nations have long provided public protection to working-age individuals with disabilities, the form has changed over time. The impetus for change has been multi-faceted: rapid growth in program costs; greater awareness that people with impairments are able and willing to work; and increased recognition that protecting the economic security of people with disabilities might best be done by keeping them in the labor market. Here we describe the evolution of disability programs in four countries: Germany, the Netherlands, Sweden, and the United States. We show how growth in the receipt of publically provided disability benefits has fluctuated over time and discuss how policy choices played a role. Based on our descriptive comparative analysis we summarize shared experiences that potentially benefit policymakers in all countries.
\end{abstract}

Keywords Disability - Disability insurance - Crosscountry comparison · Germany $\cdot$ US

\section{Mary C. Daly}

mary.daly@sf.frb.org

1 Cornell University, Ithaca, USA

University of Melbourne, Melbourne, Australia

University of Texas, Austin, USA

4 Federal Reserve Bank of San Francisco, San Francisco, USA

5 IZA Bonn, Bonn, Germany

USC Schaeffer Center, Los Angeles, USA

7 DIW Berlin, Berlin, Germany

\section{Absicherung von Personen mit Erwerbsminderung: Erfahrungen aus vier Industrieländern}

Zusammenfassung Zwar gibt es in den meisten Industrieländern seit langem staatliche Programme, die die Einkommensverluste von Beschäftigten nach Eintreten einer Erwerbsminderung ersetzen sollen, doch der Umfang solcher Programme hat sich mit der Zeit verändert. Die Änderungen ergaben sich aus einer Vielzahl von Faktoren, unter anderem einem rapiden Anstieg der Kosten, einem größeren Bewusstsein dafür, dass Menschen mit gesundheitlichen Einschränkungen in der Lage und willens sind zu arbeiten, sowie aus der Erkenntnis, dass die wirtschaftliche Absicherung von Menschen mit Behinderungen am besten dadurch $\mathrm{zu}$ erreichen ist, dass sie im Arbeitsmarkt verbleiben. Dieser Artikel beschreibt die Entwicklung der Sozialversicherungssysteme zur Erwerbsminderungsrente in vier Ländern (Deutschland, Niederlande, Schweden und USA) seit 1970. Wir untersuchen Trends in Bezug auf den Anteil an Erwerbsminderungsrentnern in den einzelnen Ländern (Anteil an Erwerbsminderungsrentnern pro 100 Personen im erwerbsfähigen Alter) sowie die Rolle, die die Politik bei der Ausprägung dieser Trends spielte. Unsere deskriptive komparative Länderanalyse fasst Gemeinsamkeiten in allen vier Industrienationen zusammen und fokussiert sich darüber hinausgehend auf das deutsche System der Erwerbsminderungsrente (vormals Erwerbsunfähigkeitsrente).

\section{Introduction}

All industrialized nations provide some form of public protection to working-age individuals with disabilities. In their early manifestations, these programs focused on easing the 
Fig. 1 Trends in Disability Beneficairies per 100 Working Age Population. (Source: Deutsche Rentenversicherung (2014a), Statistisches Bundesamt (2014), Social Security Administration, US Census Bureau; Statisitics Sweden and Swedish Social Insurance Agency yearbooks, Statistics Netherlands, and the Institute of Employee Benefit Schemes)

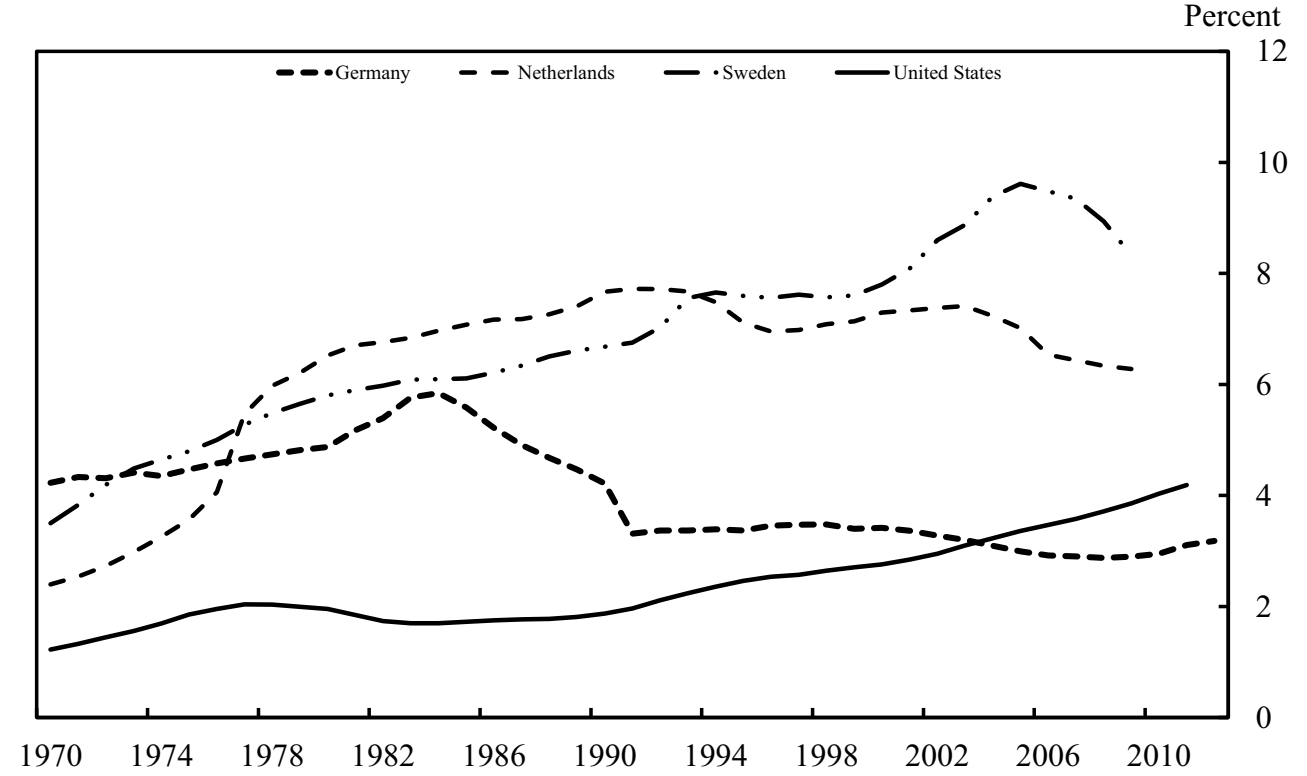

financial consequences of disability by providing cash assistance in lieu of full-time work. Over time a number of nations have moved away from simple cash assistance to emphasize pro-work programs designed to help individuals with disabilities maintain their labor market connections. On balance these changes have reflected concerns about rapid growth in program rolls as well as increased awareness that many individuals with disabilities can remain productively in the labor market.

In this paper, we describe the evolution of disability programs in four countries: Germany, the Netherlands, Sweden, and the United States. We select these countries as examples of nations with similar goals but very different approaches to achieving them. We begin by comparing trends in disability recipiency across countries. We find that all four countries experienced pronounced fluctuations in disability recipiency rates over the past 40 years. We show that these fluctuations are difficult to explain based on the relatively stable paths of variables such as health and population composition. We go on to describe changes in disability policy in each country and show that these changes are well correlated with the ups and downs in country disability recipiency rates. We interpret these correlations as suggestive of a link between policy and disability recipiency and summarize shared lessons that can be gleaned from the experiences in each nation. Although our paper is simply a descriptive comparative analysis, it highlights the similarities of experiences across nations and underscores the potential benefit of learning from other countries' policy reform efforts when tackling the challenges associated with providing social protection to those with disabilities.

\section{Disability program growth across countries}

The number of workers receiving disability-based social insurance has increased substantially in most industrialized nations over the past forty years. Population growth accounts for part of this increase, but disability caseloads as a share of the working age population age - known as the disability recipiency rate - also have risen substantially. ${ }^{1}$ This can be seen in Fig. 1, which shows the total number of persons receiving long-term categorical disability income benefits as a share of the working-age population in our four countries. ${ }^{2}$ This is the most critical number to policymakers since it measures the magnitude of the fiscal burden that these disability programs place on country finances. We show values beginning in 1970 through the last year of

\footnotetext{
${ }^{1}$ Pattison and Waldron (2013) argue that population growth explains the bulk of the rise in disability recipiency (the Disability Insurance (DI) program) in the U.S. Duggan and Imbermans (2009) and Burkhauser et al. (2014) remove the influence of population growth and consider the factors that explain the remaining rise in the program. Since population growth alone would not put additional financial pressure on the system, knowing what these other factors are is critical to policymakers tasked with funding the system. Most recently Liebman (2015) argues that most of the increase in the DI incidence rate, controlling for other factors including unemployment rates, occurred in the 1980s. Since then this controlled measure of incidence has leveled off, but at a substantially higher rate than in the early 1970s.

2 The U.S. disability recipiency rate only includes beneficiaries receiving Social Security Disability Insurance (DI). When SSI-disabled adults and DI program beneficiaries are combined, the level of the U.S. disability recipiency rate is higher, but the patterns over time are roughly the same. This point is demonstrated in Burkhauser et al. (2013), Fig. 2.
} 
Table 1 Growth rate of DI recipiency rate per 100 working population over time (geometric averages)

\begin{tabular}{lllll}
\hline & Netherlands & Sweden & United States & Germany \\
\hline $1970-1979$ & 11.15 & 5.46 & 5.57 & 1.47 \\
$1980-1989$ & 1.78 & 1.58 & -0.95 & -0.75 \\
$1990-1999$ & -0.37 & 1.41 & 4.09 & -2.70 \\
2000-Final & -1.28 & 0.91 & 3.61 & -1.58 \\
1970-Final & 2.50 & 2.25 & 2.99 & -0.96 \\
\hline
\end{tabular}

public data in each country. ${ }^{3}$ We provide a more detailed description of the data in Appendix A (Table 3).

Fig. 1 plots the disability recipiency rate (disability beneficiaries as a share of the working-age population) over time for each country. In 1970, disability recipiency rates in our three EU nations were considerably higher: $4.2 \%$ in Germany, $2.4 \%$ in the Netherlands and $3.5 \%$ in Sweden, than they were in the U.S. (1.2\%). Since then disability recipiency rates have risen substantially in each country with the exception of Germany. However, as the figure highlights, they have done so along significantly different trajectories.

To see these dynamics more clearly, Table 1 provides average annual growth rates (geometric averages) in disability recipiency by decade and over the entire sample. As the table shows, disability recipiency rates rose in all countries during the 1970s, with especially rapid growth in the Netherlands and more modest growth in Germany. In contrast, in the 1980s, recipiency rates grew more modestly and even fell in the U.S. and Germany. By the 1990s, growth in the Netherlands and Germany ended and disability recipiency rates, on balance, fell over the decade. During the 2000 s, disability recipiency rates continued to fall in the Netherlands and Germany and grew less quickly in Sweden. Growth in the U.S. slowed slightly but remained quite high relative to the EU countries in our sample.

The final average (1970-final) shows that smoothing through the fluctuations in growth that have occurred over the decades, the U.S. experienced the highest average annual growth rate over the sample period. The rapid growth in our three EU countries brought on program reforms and a tempering or reversal of the path of disability recipiency. In contrast, with the exception of the 1980s, growth in U.S. disability recipiency has been nearly continuous over the sample period.

Of course one possible explanation for the differences in growth across countries is that health and population characteristics have evolved differently for each nation over time. To understand the extent to which these factors might account for the growth in disability recipiency shown in

\footnotetext{
${ }^{3}$ Disability caseloads data are made public with a considerable lag in some countries. Hence we cannot fully document how the Global Financial Crisis affected recipiency rates in all countries.
}

Fig. 1 and Table 1, we compare trends in self-reported health across countries and more formally evaluate the role that demographics and other changes in the population eligible for disability benefits might account for trends in disability recipiency rates. We begin by examining trends in self-reported health over time and across countries. Although prone to response biases, which are well documented in the literature, the strength of the self-reported health measure is its availability across countries and over time. ${ }^{4}$ McGee et al. (1999) show that self-reported health is highly correlated with objective health measures and is a very reliable indicator of mortality.

Fig. 2 contains OECD data on self-reported health status for each of our countries. The plot shows the percentage of the population aged 45-64 in each country reporting that they are in very good or good health on a survey that asks respondents to state whether they are in very good, good, fair, or poor health. ${ }^{5}$ Since the incidence of disability increases with age, this is the most relevant age group for examining the role of health in disability benefit trends.

Although there are persistent differences across countries in the percent of individuals reporting very good or good health, there is little variation over time within countries. Over the past ten years the overall prevalence of very good or good health among working-age populations has remained relatively steady in each country. The relative stability of the health measure in each of our sample countries suggests that changes in the prevalence of impairments in the working-age population is unlikely to account for the bulk of the within and across country fluctuations in disability recipiency rates found in Fig. 1 and Table 1. Findings reported in Börsch-Supan and Jürges (2012) come to the same conclusions.

A second reason disability recipiency rates may have varied across countries over time is that the eligible populations in those nations may have evolved differently. Examples of this include increased labor force participation among women in the U.S., which increased the share of women eligible for Social Security Disability Insurance (DI) benefits. However, previous research has found that accounting for these factors cannot fully explain the differences in levels and trends across countries. See: for example Burkhauser et al. (2014) and OECD (2010).

\footnotetext{
${ }^{4}$ Some of the differences across countries may relate to the age structure of the population. Older populations report lower rates of good health than younger populations. Remaining differences likely owe to reporting differences that are idiosyncratic to each country (e. g. Jürges 2007, Ziebarth, 2010a; Van Soest et al, 2011).

5 Unfortunately, for the years considered since the 1980s, the OECD Health Statistics only includes the population shares in good or very good health, not those in fair or poor health. We take the stability of these shares as indirect evidence that the population shares in bad health have remained stable as well.
} 
Fig. 2 Trends in Self-Reported Health Across Countries, Age 45-64. (Source: Organization for Economic Co-operation and Development, OECD Health Data, http://stats.oecd.org)

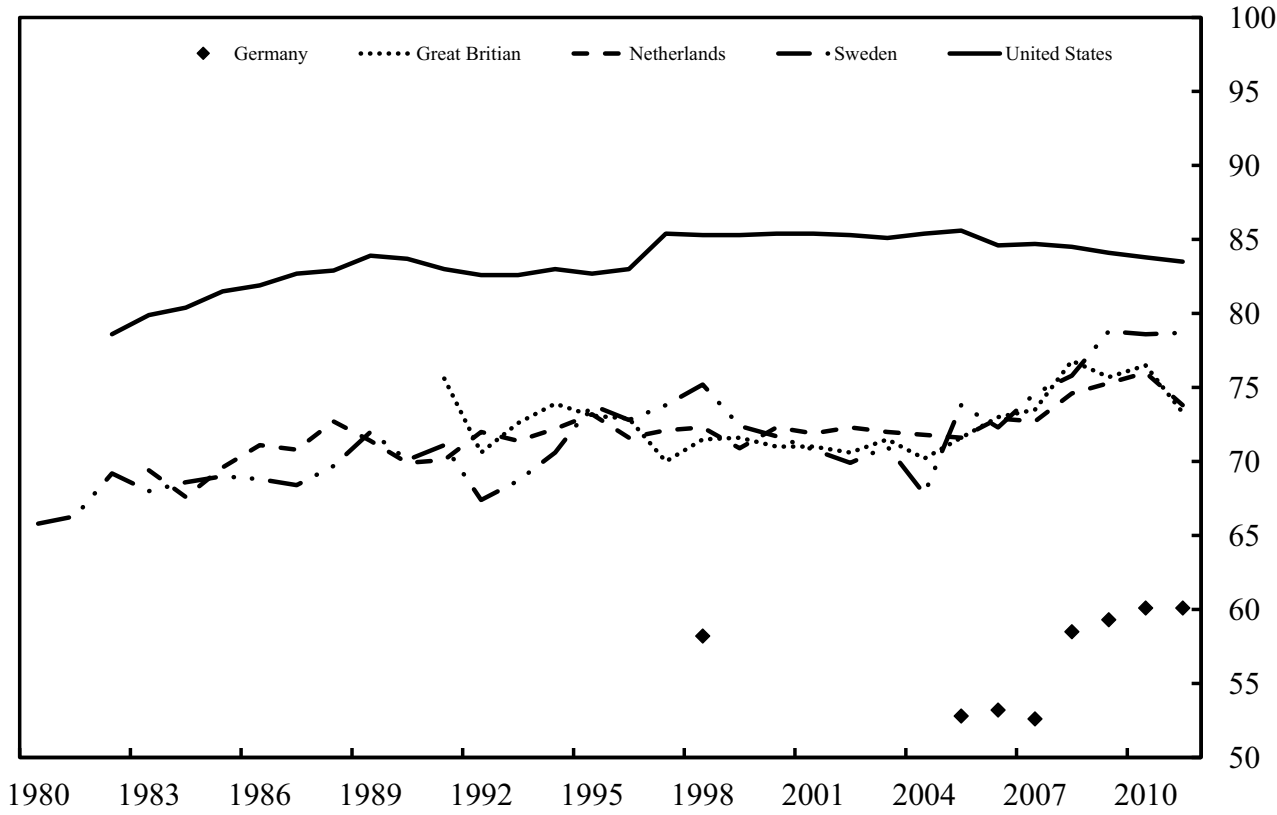

If neither health nor population characteristics can account for all of the cross-country differences in disability recipiency rates, either levels or trends, then what does? An obvious possibility is policy. ${ }^{6}$ In what follows we show how changes in disability policy and its implementation in each country are correlated with the dynamics of disability recipiency rates we documented in Fig. 1. While our comparative descriptive analysis falls short of establishing a causal effect of policy on the disability rolls, it is suggestive of the potential impact of policy design on the trends in disability benefit receipt across and within the countries in our sample.

\section{Disability policy and program growth}

In industrialized nations, social protection from income loss associated with disability is just one part of a broader social safety net designed to protect working age individuals from the loss of labor market income. Countries also provide protection to those who lose market income for other reasons such as unemployment or old age.

\footnotetext{
${ }^{6}$ We are not the first to make this point. The OECD (2010) summary of disability program growth across OECD nations concludes that policy rather than population characteristics are behind the rapid expansion of disability benefit receipt in most nations. The point is also emphasized by Autor and Duggan (2010) and Burkhauser and Daly $(2011,2012)$ for the U.S., Staubli (2011) and Mullen and Staubli (2016) for Austria, and Burkhauser et al. (2014) cross-nationally. Liebman (2015) acknowledges that policy can matter but argues this is less the case for the U.S. since the 1990s.
}

In general, countries provide this protection in tiers associated with the expectations of employment for different groups. The first tier provides universal, long-term, needsbased cash transfers that guarantee a social minimum income to all families. The second tier provides cash support to those available for employment and expected to work, but who are temporarily unemployed. These benefits are usually conditional on past work, limited in duration, and may be needs-based. The third tier targets benefits to those not expected to work - the aged, disabled, etc. - and can either be needs-based or based on past earnings. Since recipients of these benefits are not expected to return to employment, benefits are typically higher and not time limited.

When these tiers provide substantially different amounts of income and their categories are mutable, a considerable responsibility falls on program gatekeepers to consistently determine who should come onto the program. For retirement programs this is straightforward; age is an arbitrary but easily verifiable eligibility marker. Eligibility determinations by program gatekeepers will be straightforward and program caseloads will be predictable based on knowable trends in population composition.

Disability is more difficult. Unlike retirement, there is no precise definition or easily verifiable marker for determining categorical eligibility for long-term disability benefits. Moreover, disability is not a static concept and social conceptualizations of disability evolve over time. For example, over the past 20 years, the medical model of disability underlying categorical disability programs in most OECD countries has been rejected and replaced by a conceptualization that recognizes that the social environment is as important as health in determining an individual's ability to par- 


\section{Panel A. DI Recipients per 100 Working Age Population in Germany}

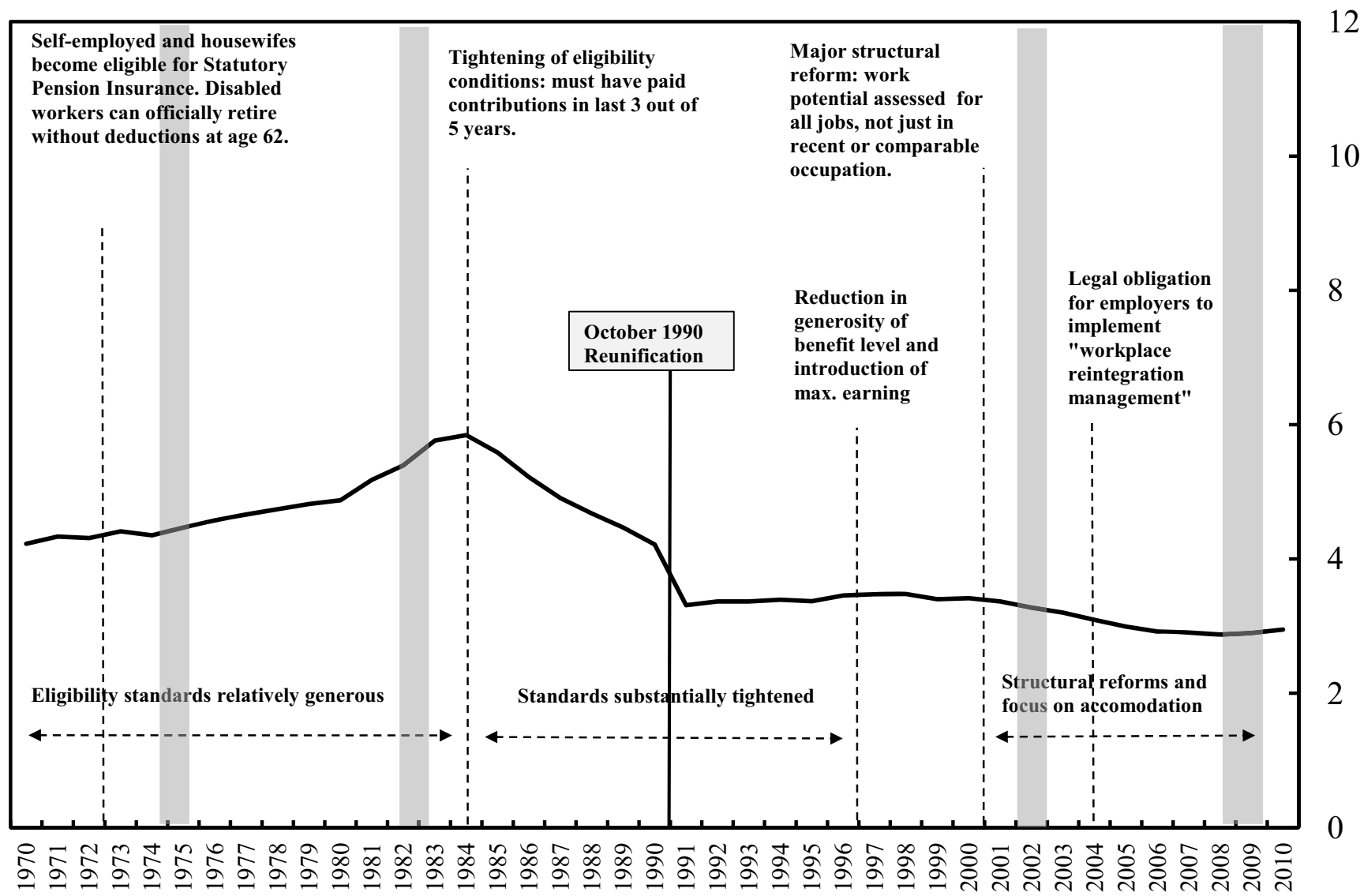

Fig. 3 Disability Recipients per 100 Working Age Population by Country and Related Reforms

ticipate in society (WHO, 2001). ${ }^{7}$ Under this model, "work disability" is a changeable state that depends on a number of factors, including an individual's health-based impairment, the level of accommodation offered in the workplace, and the relative economic rewards associated with working or exiting the labor force to receive disability benefits.

The fluid nature of the disability category has meant that changes to disability policy parameters such as who is covered for program benefits, the level of benefits - both absolutely and relative to alternative programs or wage earnings - and the breadth and severity of the qualifying conditions can influence caseload growth and disability recipiency rates. This potential is especially acute in the context of reductions in other forms of social protection or changes in the broader economy.

\footnotetext{
7 There is no clear consensus on the most appropriate conceptualization of disability, although the most widely used is the World Health Organization's (WHO) International Classification of Disability, Health, and Functioning (WHO, 2001). Burkhauser and Schroeder (2007) propose a method to harmonize classifications in surveys.
}

For example, in a number of industrialized nations, the relative value of disability benefits has risen significantly over time, as policymakers have cut payments or imposed stricter eligibility criteria on other benefit programs including unemployment insurance and general welfare. Structural changes in the economy including the declining job and wage prospects for low-skilled workers also have made disability benefits more attractive as means of long-term income support. Finally, disability benefits have increasingly become an option for displaced or long-term unemployed workers dislocated during economic downturns. Since very few disability beneficiaries ever return to the labor market, the growth in the rolls that occurs during and after recessions account for some of the long-term increase in disability recipiency rates. These rates then remain elevated until these recession induced cohorts of beneficiaries age out of the system or die. For a more detailed discussion of these issues in OECD nations see OECD (2010).

Below we discuss how disability program designs and changes in disability policy parameters in three EU countries (Germany, the Netherlands, and Sweden) and in the U.S. are related to disability recipiency rates in each coun- 


\section{Panel B. DI Recipients per 100 Working Age Population in the Netherlands}

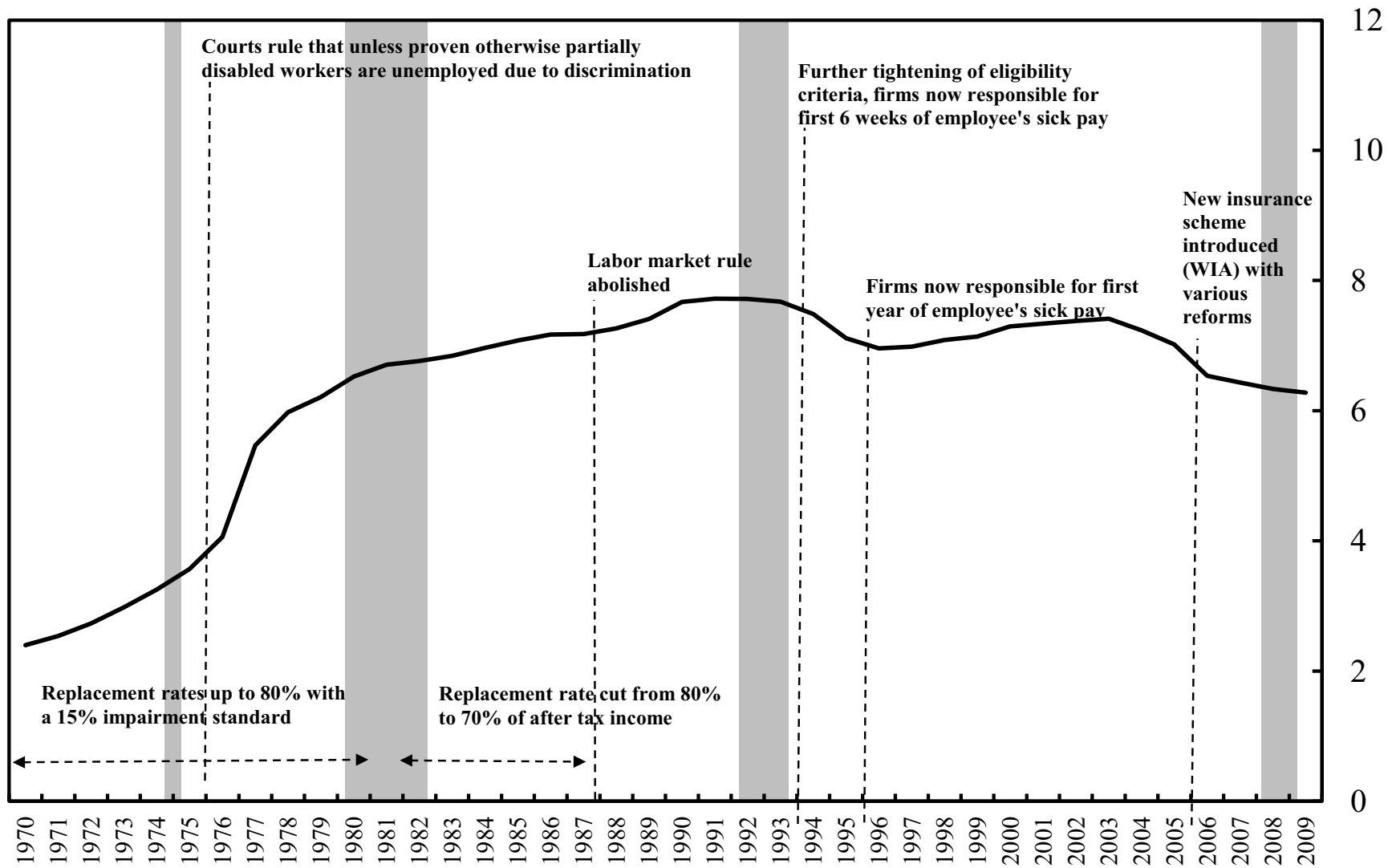

Fig. 3 (Continued) Disability Recipients per 100 Working Age Population by Country and Related Reforms

try. When relevant, we also discuss how these policy structures may have interacted with macroeconomic conditions and the broader social safety net to account for growth in the disability rolls. For reference, Fig. 3 (Panels A through D) show disability recipiency rates along with major policy changes over time for each country. Table 2 provides key information about the current state of disability programs in each nation.

\subsection{The German experience}

Germany, like most European nations, has a long-standing first-tier, universal needs-based cash transfer program that provides a guaranteed social minimum income floor to all its citizens. Benefits are funded out of general revenues. To reduce the high structural unemployment rate, the center-left government implemented major reforms in 2004 ('Hartz IV Reforms'). The reforms fundamentally altered Germany's Tier I program, cut benefits and impose job search and job training requirements on beneficiaries. ${ }^{8}$ In general, Tier I beneficiaries are considered "able to work" and part of the active labor force in Germany. ${ }^{9}$ Benefits levels are set nationally and vary across individuals based on household size and composition.

Germany also provides second and third tier benefits. Second tier benefits consist primarily of unemployment insurance (UI). To receive unemployment benefits, workers must have paid social UI contribution rates for at least 12 of the last 24 months prior to applying. Unemployed workers under the age of 50 are paid benefits (Arbeitslosengeld I) for up to 12 months. After age 50, the maximum duration increases gradually with age. For workers without

\footnotetext{
8 The 2004 reforms created the Arbeitslosengeld II program (Sozialgesetzbuch II, "Social Code Book II"). For more information about the reforms see, e. g. Eichhorst et al. (2008), Konle-Seidl (2012).

9 People are considered to be "able to work" if they are judged to be able to work at least 3 hours per day. A relatively small share of people receive Sozialhilfe (Hilfe zum Lebensunterhalt) ("Social Assistance Benefits") of a similar amount but have no job search requirement and are not considered to be in the labor force ( $\$ \$ 27-40$ SGB XII). These beneficiaries are typically "long-term unemployed" and classified as temporarily not able to work 3 hours per day.
} 


\section{Panel C. DI Recipients per 100 Working Age Population in Sweden}

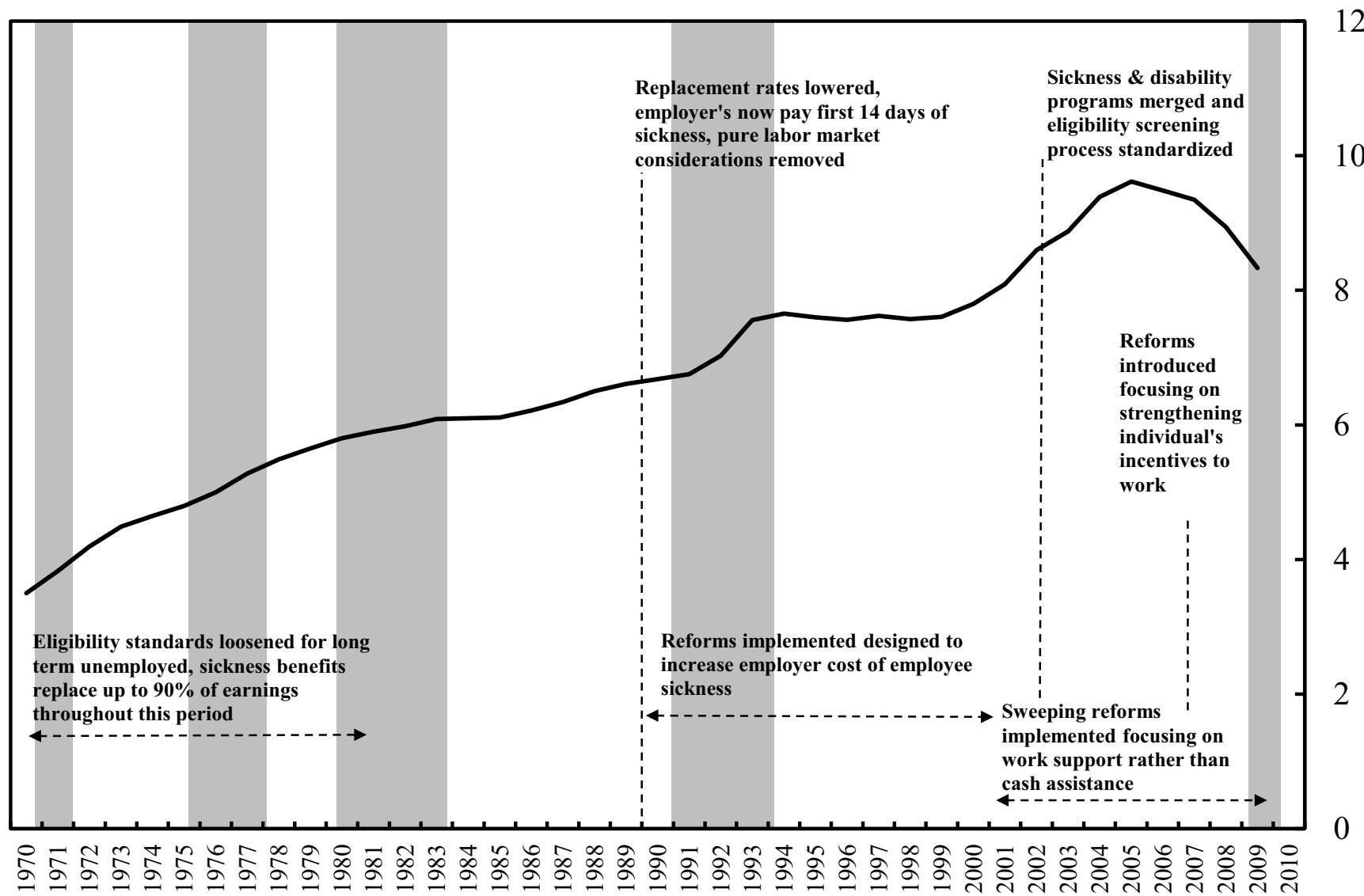

Fig. 3 (Continued) Disability Recipients per 100 Working Age Population by Country and Related Reforms

children, the UI replacement rate is $60 \%$ of the average monthly wage earnings over the previous year; unemployed workers with children receive $67 \%$ of prior earnings. Unemployment benefits are funded by payroll taxes up to the annual social insurance contribution ceiling of $€ 72,600$ $(\$ 87,000) .{ }^{10}$ Employers and employees each pay $1.5 \%$ of the gross wage.

Third tier benefits in Germany include the Statutory OldAge Pension Scheme (OAP) and the Work Disability Pension (WDP) for both partially and totally disabled workers. Both programs pay benefits to workers who have paid into the systems during their work life. Similar to UI, employers and employees are each subject to a payroll tax $-9.35 \%-$ of their monthly gross wage up to the social insurance contribution ceiling. In 2014, total WDP benefits were about

\footnotetext{
10 In the eastern states of Germany, the rates are the same but the annual social insurance ceiling is lower - $€ 62,400(\$ 75,000)$.
}

$€ 11$ billion, or $4.2 \%$ of total OPA/WDP spending (DRV, 2014a, b and c; BMAS, 2014). ${ }^{11}$

In Germany, like other EU countries, workers also are eligible for both short- and long-term statutory sickness insurance benefits. ${ }^{12}$ While these benefits can be the gateway to WDP, they are not considered Tier 3 programs because they are time limited. Employers are required to provide short-term sickness benefits. In case of sickness, workers receive $100 \%$ of their wages up to six weeks per sickness spell (Ziebarth and Karlsson, 2010, 2014). ${ }^{13}$ Workers with longer spells are reevaluated for access to long-term

\footnotetext{
11 The figure of $€ 11$ billion is based on an indirect calculation multiplying the 78,689 partial WDP beneficiaries with their annual average cash benefit of $€ 5844$ and adding the 1,224,177 full WDP beneficiaries and their average annual benefit received of $€ 8604$ (DRV, 2014a,b,c).

12 Similar to the Workers Compensation program in the U.S., Germany also has a separate Statutory Accident Insurance (SAI) program covering temporary and permanent work absences in case of work accidents or diseases. But unlike the U.S. it is administered at the federal rather than the state level.

${ }^{13}$ Short-term sick leave benefits were cut to $80 \%$ of wages in October 1996 but this reform was politically unsustainable and was reversed in 1999. For a discussion see Ziebarth and Karlsson (2014).
} 


\section{Panel D. DI Recipients per 100 Working Age Population in the United States}

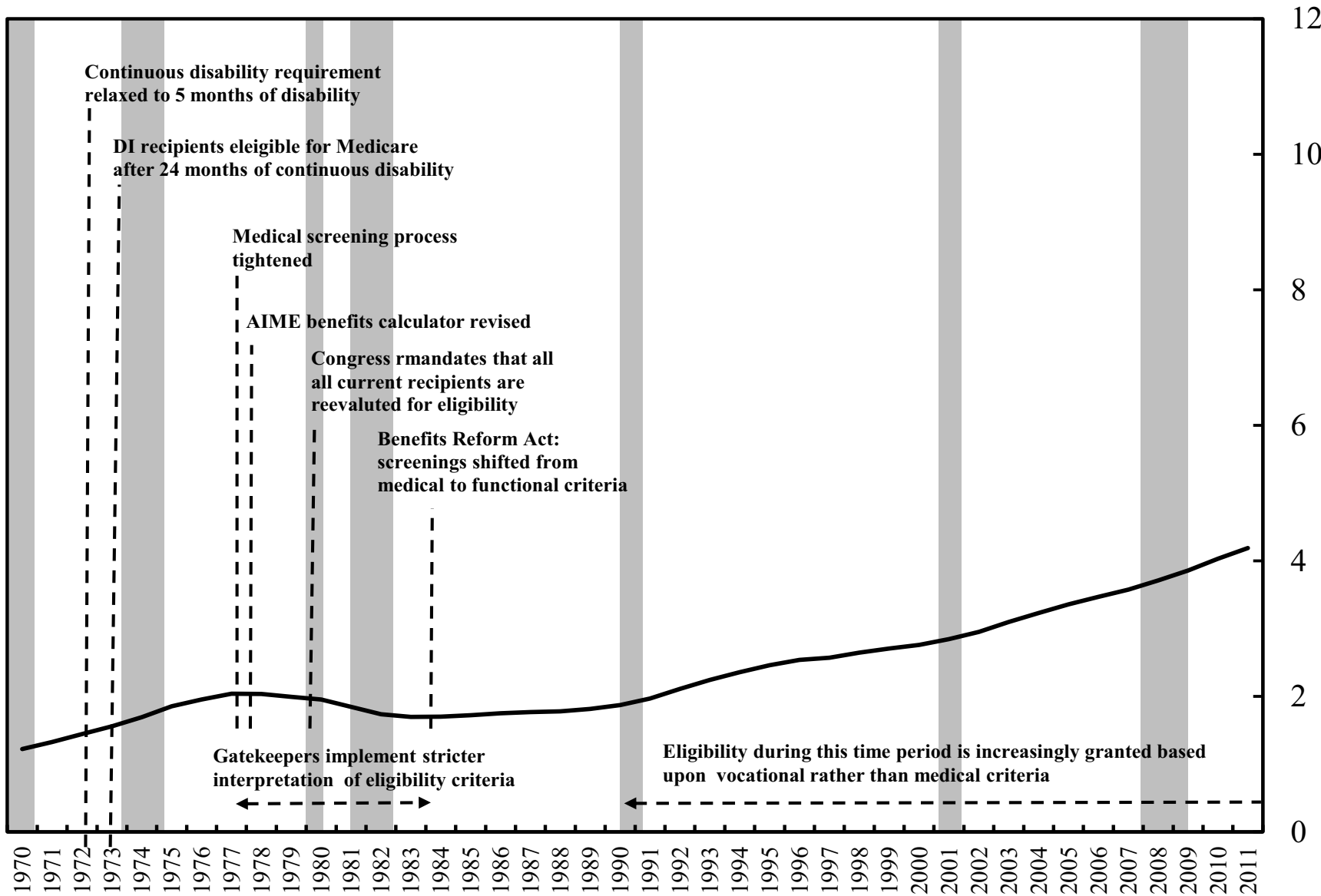

Fig. 3 (Continued) Disability Recipients per 100 Working Age Population by Country and Related Reforms

sickness benefits. These benefits are publically funded and replace $70 \%$ of net wages for up to 78 weeks (see Ziebarth $(2009,2013)$ for additional details).

In the early 1970s, of the four countries compared in Fig. 1, Germany had the highest disability recipiency rate. One element that potentially contributed to this high rate was a change in WDP rules in 1969. The reform fell into the booming post-WWII era when the social welfare state was expanded. This particular reform allowed partially disabled workers to receive full WDP benefits if they were unable to find a job (Burkhauser and Hirvonen, 1989). Further expansions in 1972 extended coverage to housewives and the self-employed. It also provided gateways to the retirement program at age 62 without actuarial benefit reductions. As seen in Panel A of Fig. 3, in the aftermath of the reforms, disability recipiency rose significantly, peaking at $5.8 \%$ in 1984 .

A substantial tightening of WDP eligibility criteria followed this rapid growth in recipiency rates. Passed by the center-right government elected in 1982, WDP reforms in the early 1980s limited eligibility to workers who had paid payroll taxes over the past three out of five years. Because many housewives did not meet these "market work criteria," this restriction greatly curtailed their WDP coverage. The strong decline in DI recipiency rates between 1984 and 1990 has been attributed to the restriction in access for women working outside the formal labor market (see RKI, 2006 as well as Börsch-Supan and Jürges, 2012 for a more detailed discussion). In the aftermath of these eligibility reforms, growth in recipiency rates turned negative (Table 1), more than undoing the increases over the previous decades (Fig. 3, Panel A).

Additional reforms were launched in the 1990s and 2000s in reunified Germany. Actuarial reductions and caps on the earnings of WDP beneficiaries were introduced in 1996. Börsch-Supan and Jürges (2012) report that the number of new male WDP beneficiaries fell from an average of about $150,000 \mathrm{p}$. a. prior to these reforms to $75,000 \mathrm{p}$. a. This strong reduction in the inflow of new male beneficiaries contributed to the decline in DI recipiency rates over 
Table 2 Disability Program Parameters Across Countries as of 2013

\begin{tabular}{|c|c|c|c|c|}
\hline & Netherlands & Sweden & Germany & United States \\
\hline $\begin{array}{l}\text { Summary } \\
\text { of Benefits } \\
\text { Program }\end{array}$ & $\begin{array}{l}\text { Merged sickness pro- } \\
\text { gram with a disability } \\
\text { program which makes } \\
\text { a strict distinction be- } \\
\text { tween fully and partially } \\
\text { disabled. Those fully } \\
\text { disabled receive guaran- } \\
\text { teed income until age } 65\end{array}$ & $\begin{array}{l}\text { Merged sickness pro- } \\
\text { gram with a disability } \\
\text { system with disability } \\
\text { benefits granted only to } \\
\text { those deemed to have } \\
\text { permanent reductions in } \\
\text { work capacity }\end{array}$ & $\begin{array}{l}\text { Merged sickness program } \\
\text { with a disability program } \\
\text { which makes a distinction } \\
\text { between fully and partially } \\
\text { disabled. Disability is de- } \\
\text { termined by ability to work } \\
\text { between } 3 \text { and } 6 \text { (partial), } \\
\text { and less than } 3 \text { (full) hours }\end{array}$ & $\begin{array}{l}\text { No mandatory sickness program. } \\
\text { Only those fully and perma- } \\
\text { nently disabled eligible for bene- } \\
\text { fits. Coverage restricted to those } \\
\text { who have paid social security } \\
\text { taxes over their working lives } \\
\text { with benefit levels tied to past } \\
\text { earnings }\end{array}$ \\
\hline
\end{tabular}

Full or Partial Benefits Program

\section{Eligibility}

Criteria

Benefits Conditional on Contributions?

Other Income Programs for the Disabled
Applicants must meet with designated doctor (either a company doctor or agency) who evaluate incapacity. Several evaluations are carried out by integration supervisors on a rolling timeline during the initial two year sickness period per day. Coverage restricted to those who have paid social insurance contribution rates with benefit levels tied to past earnings

Workers may receive sickness benefits in the event of a sickness (with approval of a doctor), however disability insurance is only granted to those with a serious and permanent impairment that reduces work ability

Sickness benefits are awarded for first 14 days with a doctors approval and reevaluated along a rolling timeline with worker "check-ins". Disability benefits are only awarded after the SIA determines work capacity is permanently reduced

Program differentiates between full and partial disability and awards benefits accordingly (see above). Coexisting employer mandate for businesses $>19$ employees: employ at least $5 \%$ severely disabled or pay penalty

Employer mandate guarantees 100 percent sick pay for first 6 weeks. Ongoing sickness is insured by statutory long-term sick pay $80 \%$ of gross wage - up to 78 weeks. Legal obligation for employer "workplace reintegration management" during long-term sickness since 2004. DI applicants must present diagnoses documenting inability to work at least 6 hours/day. Basic social insurance principle: "Rehabilitation before Pension."

Yes, 3 out of last 5 years of coverage necessary before onset of disability. Waiting period of 5 years

of benefits awarded. A universally guaranteed pension provides assistance to all those residing in Sweden. The earnings related pension is contingent upon weeks of work and past earnings those who have severe, long-term disabilities meeting specific criteria other public services de-
Assistance Allowance, Car Allowance and other programs are designed to accommodate

Specific income tax deducAssistance Program (SA) with benefit equal to minimum wage tions, 2 years of earlier regular retirement, subsidized public transportation and signed to accommodate those who are classified "severely handicapped" (disability degree at least $50 \%$ )
Yes, sufficient quarters of coverage necessary as defined described in Social Security Administration (2013b)

Workers Comp and SSI and private disability insurance 
the rest of the decade, as evidenced in Fig. 3, Panel A and Table $1 . .^{14}$

Another round of structural WDP reforms was introduced in 2001. Most important was the tightening in the work-limited eligibility standard from "being unable to work in the occupation in which one was trained" effectively in the last job or a comparable job in terms of the skills it required, the wages it paid and its prestige - to "being unable to work in any job available in the economy" (change from Erwerbsunfähigkeitsrente to Erwerbsminderungsrente). As we will describe later, this reform made eligibility for WDP benefits stricter than the typical eligibility criteria in the private market for DI benefits. Following this policy change, total inflows onto the WDP program decreased further, falling from 200,000 in 2001 to 160,000 in 2005 (Krause et al. 2013, DRV 2014b).

WDP reforms in 2004 continued to focus on reducing the inflow of new recipients. However, the attention shifted away from tightening WDP eligibility requirements towards promoting worker accommodation on the job. Specifically, the reforms mandated employers to provide workplace reintegration management programs. Indeed, the law requires that when impaired workers exhaust their shortterm sickness benefits (six weeks) and are being considered for longer-term sickness benefits, employers must coordinate a plan that includes input from: the sick-listed employee, WDP experts, the worker council, and the workplace physician. The plan is meant to ensure that the employee's temporary work disability can be overcome and to prevent future reductions in work capacity.

The experience of Germany over the past four decades is a useful illustration of the role that policy decisions can play on the dynamics of disability recipiency rates. When Germany was expanding both the coverage and generosity of disability benefits, recipiency rates were high and rising relative to other countries. WDP program growth subsequently declined in the aftermath of reforms that limited access, made benefits less attractive and required employers to implement a workplace reintegration program. Germany is the only country in our sample whose disability recipiency rate is now below its 1970 level. As can be seen in the bottom row of Table 1, annual growth rates over the entire period of our analysis (1970 to our most recent year of data) averaged $-0.96 \%$ in Germany compared to $+2.50 \%$ in the Netherlands, $+2.25 \%$ in Sweden and $+2.99 \%$ in the U.S.

Private Disability Insurance. Notably, the policy changes in Germany that reduced the size of the public WDP program were correlated with an increase in the

\footnotetext{
${ }^{14}$ Note that the figures reflect the stock of all beneficiaries. As such, even large declines in the inflow of new beneficiaries only gradually translate into overall DI rate declines.
}

market for private disability insurance (Fig. 4). The majority of private DI policies provide benefits to covered workers who have established that a health shock led to reduced work capacity in the current (or a comparable) occupation (Berufsunfähigkeitsversicherung as compared to Erwerbsunfähigkeitsversicherung ) - a less difficult level of work incapacity to meet for benefit eligibility than the one imposed by WDP since 2001. As shown in Fig. 4, the number of new private DI policies in Germany grew slowly from 1976 through the mid-1990s. But growth increased substantially around the introduction of actuarial reductions and caps on the earnings of WDP beneficiaries in 1996. Growth in new private policies increased further in 2001. This is the year that WDP eligibility was limited to workers who were unable to perform any work in the economy. ${ }^{15}$ In 2012, $61 \%$ of employed men and $42 \%$ of employed women were covered by private disability insurance (Statistika, 2014). ${ }^{16}$

While the expansion of private disability insurance suggests that many Germans responded to the reductions in public WDP benefits by purchasing alternative private policies, to our knowledge no research on this substitution has been published. Even if individuals are augmenting the WDP program with private insurance, the substitution is likely not perfect. Private disability insurance plans are experience rated and individually underwritten. Private disability insurance follows private insurance law and is based on a private contract between the insurer and the insured, which specifies the conditions for the insured risk individually. Premiums depend on age, medical diagnoses, and occupation. As a result, premiums can be very high for high-risk occupations and applicants may be denied coverage.

\subsection{The Netherlands ${ }^{17}$}

As in Germany, the disability system in the Netherlands contains both a social insurance program that protects workers against lost labor earnings and a program that provides a social minimum for disabled adults with little or no work history. A separate social minimum scheme for the disabled

\footnotetext{
15 Conversations with German Association of Insurers (GDV) representatives confirm that no industry-specific supply-side factors have been driving this trend.

16 Beneficiaries of private disability insurance may also receive WDP benefits if they are eligible. This contrasts with the U.S. market where private insurers may reduce payments dollar for dollar for recipients of public Social Security Disability Insurance. This means that private insurers in Germany have more of an incentive to return beneficiaries to work than do those in the U.S. (see Burkhauser and Daly 2011 for a fuller discussion of this point).

17 A longer version of this summary of the Dutch system can be found in Burkhauser and Daly (2011).
} 
Fig. 4 New Private DI Policies in Germany. (Source: Association of German Insurers (DGV))

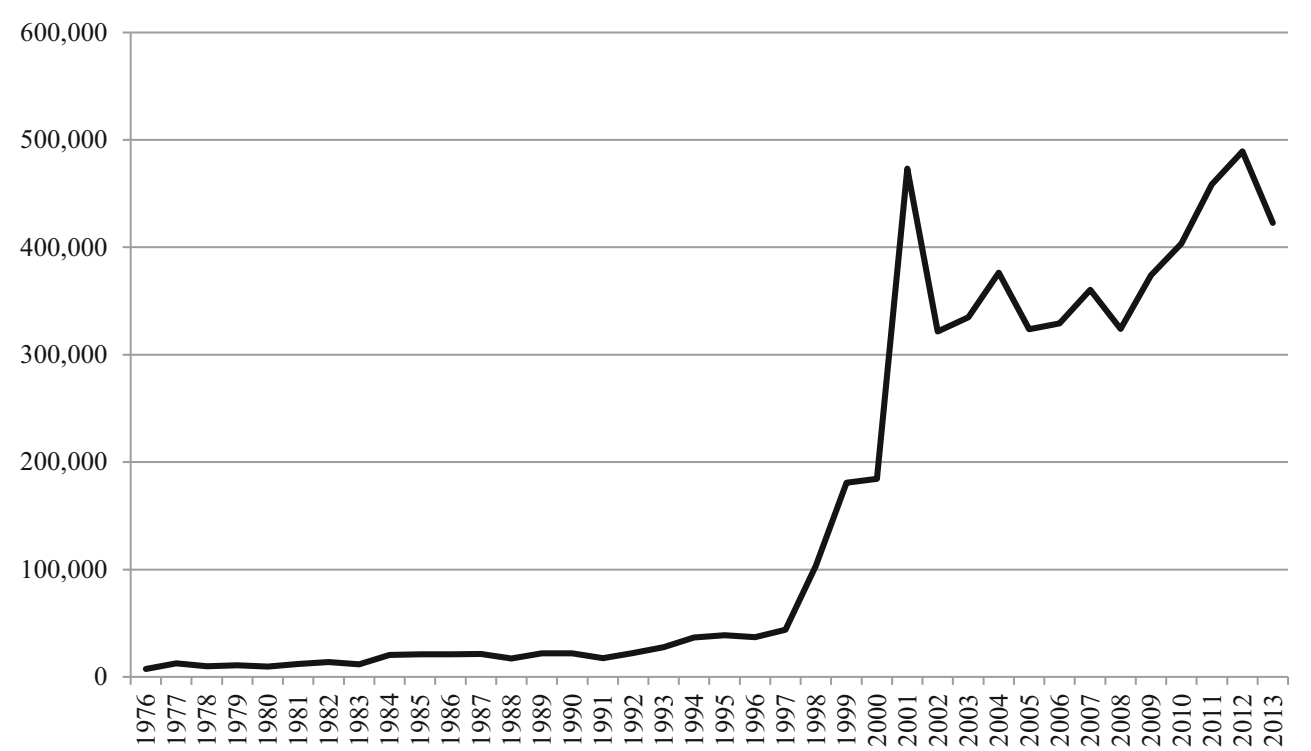

self-employed ended in 2004. The Dutch social insurance program (WAO/WIA) provides cash transfers to workingage men and women based on lost labor earnings. The Netherlands does not have a separate program similar to Workers' Compensation in Germany, Sweden or the U.S. Rather it has a longer-term disability transfer program that, together with sickness benefits all private firms must offer, provides a comprehensive system of both partial and total disability benefits to workers regardless of how or where their disability occurred. The Dutch also have a categorical disability-based welfare program (Wajong) that, unlike the general welfare scheme, is not means tested. This program is similar to the SSI-disabled adults program in the U.S. It targets men and women whose disabilities occurred prior to their entrance into the labor force and are severe enough that they have not engaged in full-time employment as adults (see Table 2 for details of the disability program in the Netherlands).

The Dutch disability program grew rapidly over the 1970s. This was a time when the system provided relatively generous benefits (Fig. 3, Panel B). In the 1970s, government payments from the universal sickness benefit system - essentially a universal short-term disability system - replaced up to $80 \%$ of net wage earnings for up to one year. And most employees $(90 \%)$ had the rest of their netof-tax earnings replaced by collective-bargaining agreements with their employers. These disability replacement rates were far in excess of comparable programs in the U.S. and many other European nations. Sickness benefits were payable for up to twelve months. After one year, employees still receiving benefits were eligible for disability benefit screening. Workers with chronic conditions that caused a reduction in their capacity to perform work commensurate with their job training and work history were eligible for disability benefits. Those judged fully disabled were eligible for benefits equal to $80 \%$ of their gross earnings. Those judged partially disabled (those with some residual earnings capacity) were eligible for partial benefits; the minimum degree of impairment for eligibility was $15 \%$.

In a significant loosening of access to full disability benefits in the mid-1970s, Dutch courts determined that unless disability evaluators could prove otherwise, they were required to attribute a partially disabled worker's lack of employment to discriminatory behavior. The result was that it became "administrative practice" to treat unemployed, partially disabled persons as if they were fully disabled. That interpretation of the law made assessing lost earnings capacity unnecessary beyond the minimum $15 \%$. This practice essentially made the Dutch partial disability system a very generous full disability program. Consequently, in the 1970s, the disability recipiency rate in the Netherlands grew $11.15 \%$ per year (Table 1; Fig. 3, Panel B).

Reforms initiated between 1982 and 1987 were the first of three major efforts over the next two decades to regain control of the Dutch disability transfer system. By 1985, a series of cuts in the replacement rate effectively lowered it from $80 \%$ of gross earnings to $70 \%$ of net earnings for both new entrants and current beneficiaries. In addtion, in 1987 the labor market consideration rule was completely abolished. Despite the legal ban on including labor-market considerations in their assessments, disability adjudicators still tended either to grant or deny full benefits. Denial rates remained quite low, suggesting that the legal change did not stop the de facto use of labor-market considerations in the adjudication process. Nonetheless these changes were accompanied by slower growth in disability recipiency in the 1980 s, on average $1.78 \%$ per year (Table 1). This 
brought the Netherlands more in line with disability growth in Sweden.

In 1994, the Dutch government introduced several additional reforms including measures to further tighten eligibility criteria. And in a new policy, private firms were made responsible for an employee's first six weeks of sick pay. The introduction of some "privatization" of the disability system was new in the Netherlands and represented a change in policy intended to encourage firms to provide accommodation, rehabilitation, and continued employment opportunities to workers as an alternative to moving them onto long-term cash benefits. The mandate that firms would bear the full responsibility for sick pay was extended from six weeks to one year in 1996. Despite these reforms, the decline in the Dutch disability recipiency rate stopped in 1997. It began to slowly climb again. Still, the average growth in the beneficiary rate in the 1990s was a mere negative $0.37 \%$ (Table 1 ).

In 2002, the Dutch disability system began to phase in the third and most significant set of reforms. These reforms culminated in the establishment of a new disability insurance scheme in 2004 - WIA - which replaced the WAO scheme that had been in place since 1967. These systemic reforms fundamentally altered disability policy in the Netherlands. The reforms deliberately made work rather than cash benefits the expectation and enforced this by increasing the incentives of both employees and their employers to invest more time and effort in accommodation and rehabilitation following the onset of a disability.

Foremost among the reforms was the extension from one year to two years of the mandate that firms (including small employers) bear full responsibility for employees' sick pay. These changes effectively meant that during the first two years following a health shock, workers were the responsibility of the firm and not eligible for long-term government provided disability benefits. During these two years, employers were required to allow workers receiving sickness benefits to remain with the firm; dismal was allowed only for employees who refused to cooperate in a reasonable work-resumption plan.

The reforms also gave firms a list of prescribed rehabilitation and accommodation activities that they (via a private occupational health agency) had to provide to assist workers in remaining on the job or finding alternative employment. When the two years were complete, workers were allowed to apply for long-term disability benefits, but they were required to provide documentation regarding return-to-work efforts during the two-year period. In 2007, nearly $14 \%$ of disability insurance claims were returned to employers and the employer continued to be responsible for employing the worker until the claim was processed or the worker had returned to the old or a new job.
Reforms at the front end of the process were accompanied by significant reforms in the longer-term benefit program. All employers were made to pay for the full and permanent disability program through a uniform pay-asyou-go premium rate. Employers also had to pay to fund the publicly run partial disability program, but they could opt out of it by enrolling their workers with a private insurer instead. Either way, employers had to pay experience-rated premiums that covered the first ten years of partial disability benefit receipt. After ten years, the financial burden would shift to the uniform pay-as-you-go rates that also cover the fully and permanently disabled and the stock of current beneficiaries under the old system. Table 1 shows that the average growth rate in the Dutch DI program was $-1.28 \%$ in the new millennium.

Borghans et al. (2014) provide evidence that the reduction in benefits for current Dutch disability insurance recipients in the reforms of 1992/1993 lead to both their increased use of alternative social welfare programs and greater earnings from employment over the next decade. They argue that, on average, increased income from these two alternative sources fully offset the cut in their DI benefits. While it is still too early to determine the full effect of more recent policy changes on the Dutch disability beneficiary population, Van Sonsbeek and Gradus (2011) provide the first micro-simulation of the consequences of the post-2002 round of policy changes discussed above. They estimate that the combined impact of the introduction of experience rating together with the introduction of the statutory Gatekeeper Protocol and stricter examinations will reduce the projected long-term number of disability beneficiaries by 600,000 . The also estimate that the introduction of the new WIA scheme will further reduce that projected number by 250,000 by 2040 , as compared to a "no-change scenario." Koning and Lindeboom (2015) provide the most recent review of the consequences of the Dutch disability reforms on program enrollment and a review of the literature on this topic.

Overall, the research on the effectiveness of the Dutch disability reforms supports the ideas that policy design matters for the outcomes of individuals with impairments and suggests that, with assistance, many workers who experience a health shock can remain productively in the labor market.

\subsection{Sweden}

Like most European nations Sweden has a long-standing first-tier, universal needs-based cash transfer program that provides a guaranteed social minimum income floor to all its citizens. This first-tier protection is funded out of general revenues and is available to everyone who lives or works in Sweden. Although benefits provide minimum in- 
come to anyone in need, applicants apply for benefits based on income and particular circumstances, such as disability, parental needs, or old age. Benefits are set nationally and indexed to keep pace with the price level.

Sweden also provides second and third tier benefits. The second tier in Sweden includes unemployment insurance benefits, which include both a mandatory and voluntary component. The mandatory component is paid for by all employers and replaces a minimum fraction of wages for covered workers. The number of weeks covered by unemployment insurance has fluctuated over time but is generally longer than in the U.S. Most individuals also are covered by voluntary unemployment insurance which is negotiated between firms and trade unions. Somewhat uniquely among the countries we review, Sweden also has many private options for unemployment insurance; these may be purchased individually or through an employer.

Sweden provides third tier benefits, including old-age pensions and sickness and disability benefits, through a combination of programs. For those with an earnings history, the bulk of the protection is provided based on a social insurance program that, as in the U.S., is financed by statutory employer and employee contributions. Many employers in Sweden also pay into occupational-based insurance and pension programs on behalf of their employees. Participation in these schemes is driven by competitive forces or collective bargaining agreements with unions but a majority of employers in Sweden participate in these programs. Table 2 provides more details about the Swedish disability system.

As in the Netherlands, the Swedish disability program was relatively generous and expanding rapidly in the 1970 s with average annual growth rates of $5.46 \%$ (see Table 1). The first level of protection for Swedish workers with health problems is a sickness benefit. In the 1970s, sickness benefits replaced about $90 \%$ of expected earnings for individuals with "abnormal physical or mental conditions" that reduced their normal work capacity by at least $25 \%$. Workers claiming sickness absence for more than eight days were required to get a certificate from a doctor. This was primarily facilitated by the individual's doctor with no centralized screening or standards.

After one year, employees still receiving benefits could apply for long-term disability insurance. Workers with functional limitations that caused a reduction in their capacity to perform work commensurate with their job training and work history were eligible for disability benefits. Benefits were awarded for partial (50\%) and full disability (Andrén 2014). For those under age 60, benefits included rehabilitation and vocational training. For those 60 and older, beneficiaries were provided income support. Like sickness benefits, disability benefits were very generous replacing the vast majority of lost earnings.
Over the course of the 1970s, standards for obtaining long-term disability benefits were also loosened to make it easier for the long-term unemployed to move onto the program. For workers of all ages, unemployment spells of more than one year were added to the list of criteria considered in the disability screening process. For workers over age 60 , long-term unemployed became a sufficient condition for moving onto disability benefits, even without a certifiable functional limitation. Similar to the Dutch case, these changes meant that the disability benefit program was increasingly being used as a very generous longterm unemployment insurance program..$^{18}$

Generous benefits and easier access correlated with steady growth in disability recipiency rates over the 1970 s and 1980s (Fig. 3, Panel C). These features also left the program vulnerable to growth related to the serious recession in the early 1990s. As shown in Fig. 3, Panel C, following the foreign exchange crisis in 1990 and ensuing deep recession, disability recipiency rates surged. Policymakers responded by lowering the replacement rates on sickness benefits, making employers pay for the first 14 days of sickness absence, and removing the pure labor market criteria for disability benefits for older workers. With these changes to policy and an improving economy, disability recipiency rates stabilized for most of the rest of the decade. That said, they remained relatively high and at a level that some policymakers argued was unsustainable. As such, additional policy reforms were made throughout the 1990s. These reforms were designed to increase the employer cost of worker sickness absence and increase the threshold for workers applying for sickness and/or disability benefits. ${ }^{19}$

Facing increasing fiscal pressures and a renewal of disability recipiency rate growth (Fig. 3, Panel C), in 2000 the Swedish government proposed much more sweeping reforms to the sickness and disability system. Despite considerable opposition from various advocacy groups, significant reforms were put into place over the remainder of the decade. The driving principle behind the reforms was that work support, rather than cash assistance in lieu of work, was the primary goal of disability policy.

This general principle translated into a number of important specific reforms. In 2003, the government merged the sickness benefits and disability systems and began a series of changes to standardize and enforce the administration of

\footnotetext{
${ }_{18}$ Econometric studies of the Swedish system support this view. See for example Rebick (1994) and Larsson (2006).

19 The Swedish government made numerous changes to sickness benefit replacement rates, the number of days the employer paid for employee sickness absence, and the number of days the worker had to wait before receiving sickness benefits (Andrén 2003). In addition, policymakers removed most of the special allowances for disability insurance afforded to unemployed and older workers (Jönsson et al. 2011).
} 
these now joint systems. Most notable among them was the centralization of screening processes. Up until this point, certification for sickness benefits had been variable as had disability benefit allowance rates. Although rehabilitation and vocational training were goals, many doctors and regional disability gatekeepers focused on providing income support rather than employment retraining. By centralizing the process and developing standardized protocols for granting cash benefits, policymakers were better able to regulate the gatekeepers and enforce the strategy of promoting participation in work before offering cash benefits. Although it is too early to judge the effectiveness, the idea is that this standardization will temper the link between regional economic conditions and disability recipiency that had historically been present.

In addition to standardizing the screening process, the merger of the sickness and disability programs forced disability gatekeepers to become actively involved early in the process. By getting vocational and rehabilitation experts involved early, at the sickness benefit stage, policymakers intended to stem the flow of new applicants to the long-term disability program. To aid in this process, sickness benefits were capped at one year, and beneficiaries were evaluated for work ability at 180 days of absence. Only those who could show that they had no capacity to perform any job were allowed to remain on the program for the full year. In addition, employers were required to work with disability administrators to create a rehabilitation plan. And gatekeepers were given the power to demand that employers provide certification about the types of accommodations they made for the worker. In the aftermath of these reforms, the use of sickness benefits declined as did the flow of new beneficiaries onto the long-term disability system. This correlation between policy changes and declines in benefit use, to our knowledge, has not been causally established in published research.

In 2008 the Swedish government undertook an additional series of reforms to its sickness and long-term disability programs (these reforms are detailed in Hartman (2011) and OECD (2009)). These reforms were meant to further curb growth in the rolls and more actively return newly impaired workers to back to the labor market. The 2008 reforms went beyond engaging gatekeepers and employers and focused on individuals with disabilities. New rules aimed at strengthening the incentives for individuals with disabilities to work and improving their opportunities to do so. The principal reform was the establishment of a new timeline for the provision of rehabilitation services under the sickness absence program with checkpoints closely aligned with assessment of work capacity and a reduction of the cash value of sickness benefits for those who did not return to work. In addition to adding more checkpoints, the reforms also front-loaded the evaluations so that they were being done at 3-, 6-, and 12-month increments. The earlier checkpoints provided rehabilitation, counseling and assessment much closer to the onset of an impairment when return to work was more likely.

After the reforms, new sickness program entrants returned to work more quickly and reduced their overall time on the program (Hartman, 2011). In contrast, few of those already on the sickness program when the new reforms were initiated ever returned to work. These findings provide support for the idea that early intervention matters. Waiting even one year following the onset of impairment significantly reduces the chance that rehabilitation will result in a return to work. The disability reforms put in place by the Swedish government late in the 2000s appear to have helped curb growth in disability recipiency rates in the nation (Fig. 3, Panel C).

\subsection{The U.S. experience}

Unlike the three EU countries discussed above, the United States has no first-tier, universal needs-based cash transfer program that provides a guaranteed social minimum income floor to all its citizens. The Supplemental Security Income (SSI) program, which is limited to the aged, disabled adults and parents of disabled children, is the only long-term needs-based cash transfer program. ${ }^{20,21}$ The only other major categorical needs-based cash transfer program in the U.S. is Temporary Assistance for Needy Families (TANF), which is targeted at single mothers and provides an even lower guaranteed income level and the guarantee is limited to 5 years.

The second tier in the U.S. includes unemployment insurance benefits, which replace a fraction of wages for covered workers for short periods of time. In normal economic times, unemployment benefits can last up to 26 weeks. During recessions, this maximum is often extended and it rose to 99 weeks in the aftermath of the Global Financial Crisis. Unemployment insurance benefits are generally higher than SSI or TANF benefits.

The social security Old-Age Retirement and Survivors Insurance (OAI) and Disability Insurance (DI) programs make up the third tier of benefits in the U.S.; they provide social insurance to workers who have paid social security

\footnotetext{
${ }^{20}$ SSI is similar in design to the Dutch categorical disability-based welfare program (Wajong) but its income guarantee level is substantially lower than either.

21 The SSI aged and disabled adults programs share the same categorical eligibility criteria applied for the earnings based retirement or OldAge Retirement and Survivors Insurance (OAI) and Disability Insurance (DI) programs. Individuals with sufficiently low earnings records may jointly qualify for OAI and SSI aged benefits and for DI and SSI disabled adult benefits. This said, these programs are generally treated separately by policymakers.
} 
taxes over their working life. ${ }^{22}$ To be eligible for benefits, workers must have accumulated sufficient quarters of coverage, as defined in the Social Security Administration's pension rules. These requirements are sufficiently strict to limit OAI and DI benefits to those with substantial attachments to the labor market (for a summary of the benefit requirements and rules, see Social Security Administration (2013a)). Benefit levels from these programs are based on past earnings. They can be substantially higher than the benefits guaranteed by the SSI aged and disability programs.

Eligibility for DI benefits requires applicants to meet a federal disability standard applied by administrative evaluators and adjudicators located in each state. The criteria are in principle quite strict. Eligibility requires that a worker be "unable to perform any substantial gainful activity on any job in the economy for at least one year". There is no benefit for partial disability. Disability benefits are intended to be a last-resort for those with permanent and total impairments. Table 2 provides more details on the U.S. DI program.

Although the written eligibility criteria have not changed over time, their implementation has changed in a direction that has increased the number of working-aged adults receiving disability benefits. Indeed, many of the disability recipiency rate fluctuations shown in Fig. 1 and Table 1 line up with changes in Social Security Administration (SSA) policies. For example, rapid disability recipiency rate growth of an average of $5.57 \% \mathrm{p}$. a. in the 1970s aligns with Congressional actions that increased the replacement rate for a disabled worker with median earnings from 35 to $49 \%$ (Fig. 3, Panel D). In the late 1970s and early 1980s disability recipiency rates fell, first because program gatekeepers were urged to more strictly interpret existing rules. And then because, in 1980, Congress required SSA to reevaluate all current recipients to see if they still met the medical standards. This rule change, which was rigorously enforced by SSA at the start of the new Reagan administration, resulted in a drop in the DI rolls despite a major recession - the substantial drop in normalized adjusted disability recipiency rates in the U.S. between 1978 and 1983 are in stark contrast to the sizable growth in these values before 1978 and after 1990 (Fig. 3, Panel D).

By 1983 the widespread reevaluation of those already on DI was halted as the courts and then Congress restricted the SSA's power to reevaluate beneficiaries. Furthermore, in 1984, responding to a backlash against restrictive cuts imposed in the Social Security Disability Amendments of 1980, policymakers expanded the ways in which a person

\footnotetext{
${ }^{22}$ Autor et al. (2014) provide a detailed analysis and discussion of the private disability insurance market in the U.S., which is significantly smaller than the private market in Germany.
}

could medically qualify for the DI program. The 1984 legislation moved away from a strict medical listing determination of eligibility to one that also considered an applicant's overall medical condition and ability to work. In addition, the legislation allowed for symptoms of mental illness and pain to be counted when assessing DI eligibility, regardless of whether the person had a verifiable medical diagnosis (Fig. 3, Panel D). ${ }^{23}$

The expansion of eligibility to more difficult to measure impairments that do not precisely meet the medical listings means that SSA has increasingly been tasked with making more subjective decisions about the impact that impairments might have on an applicant's work ability. For applicants who do not meet the medical listings, program administrators consider a set of vocational criteria. While these vocational criteria have been in place over the history of the DI program, their use by program gatekeepers to determine benefit eligibility has risen dramatically since 1991. Currently, they are used to justify the majority of new awards, especially among those with the more difficult to determine conditions of mental illness and musculoskeletal conditions - the primary condition of more than $50 \%$ of all newly enrolled beneficiaries (Burkhauser and Daly, 2011).

One consequence of expanding eligibility beyond identifiable medical listings is that DI applicants and gatekeepers have much more of a role in determining program growth. For example, over time, the cyclical sensitivity of DI application rates has risen considerably. Applications rise during recessions and fall during periods of economic growth (see Rupp and Stapleton, 1995; Stapleton et al. 1998; Black et al. 2002; Autor and Duggan, 2003; Liebman, 2015). But as can be seen in Fig. 3, Panel D, increased applications generally result in an increase in disability recipiency rates which do not subside as economic conditions improve. Once on, very few beneficiaries ever leave the program.

In addition to the cyclical sensitivity of disability applications and awards, there is evidence that there has been a secular rise in the number of workers who apply related to the (unintentional) increase in the DI replacement rates for low wage workers (Autor and Duggan, 2003). Bound and Burkhauser (1999) provide an early review of the literature on the labor supply effects of disability insurance. Since then researchers have consistently found a negative effect of DI program work constraints on employment - see Chen and van der Klaauw (2008), von Wachter et al. (2011), or Moore (2015). Again, since few beneficiaries ever leave the rolls, the surge in disability recipient rates associated with business cycle fluctuations or economic restructuring has generally translated into a long-term increase in disability recipiency rate in the working age population.

\footnotetext{
${ }^{23}$ See Berkowitz and Burkhauser (1996) for more discussion of these changes and their effects.
} 
Finally, there is evidence that the strictness of DI gatekeepers also varies. Using SSA administrative records, Maestas et al. (2013) estimate that $23 \%$ of applicants are initially accepted or denied based on whether they were assigned an easier or a stricter DDS gatekeeper rather than on differences in the status of their health or impairment status.

\subsection{Why has the German experience been so different?}

As seen in Fig. 1 and discussed above, recipiency rates in Germany's WDP program fell between 1984 and the reunification in 1989 and have almost continuously done so since then. This pattern stands in contrast to the Netherlands, Sweden and the U.S. where recipiency rates have increased considerable since the 1970s. While the rates in the Netherlands and Sweden have come down from recent peaks of $7.4 \%$ in 2003 (Netherlands) and $9.6 \%$ in 2005 (Sweden) they have reached a new record high of $4.2 \%$ in the U.S. in 2011. As a result, Germany now has the lowest recipiency rates of government provided disability insurance benefits among these four nations.

What accounts for the decline in Germany both in its rates over time and relative to other countries? Our reading of the data is that the relatively restrictive coverage and eligibility conditions have shifted the costs of DI coverage, especially since 2001, to individuals (and their employers). This shift is evident in the fact that over $60 \%$ of male and $40 \%$ of female employees contract for private disability insurance to augment their public insurance coverage. In addition, WDP benefits, when available, have declined in value over time. This reduction in the social safety net for workers with disabilities has been cited as contributing to the high poverty rates among public disability beneficiary households fall below the poverty line (Krause et al. 2013).

Another more positive reason for the decline is that Germany has been increasingly implemented one of the main social insurance principles "Rehabilitation before Pension" emphasizing the overall focus on maintaining work ability. As a result, Germany has one of the largest medical rehabilitation markets. In 2011, 1.9 million rehabilitation therapies were prescribed and a total of $€ 8.9$ billion are annually spent (cf. Ziebarth, 2010b, 2014). This commitment to rehabilitation while workers are receiving temporary earning replacement as part of their sickness benefits may have played a role in curbing growth in the WDP program.

Finally, the German social insurance scheme is part of a larger context of protections and expectations for worker with disabilities. Germany has a coexisting Disability Classification System (DCS) which is codified in Social Code Book IX (SGB IX) and entitled "Rehabilitation and Partic- ipation of Handicapped Workers." 24 This DCS system identifies citizens with health impairments and assigns them a handicap rating by medically-based impairment categories. Only permanent health impairments lead to a classification. For example, a mild form of Parkinson disease without imbalance issues but "mild motion disorders" yields a disability degree of $30-40 \%$ whereas more severe forms of Parkinson lead to degrees of $50 \%$ and above (BMAS, 2009). A person with a rating of $50 \%$ and above is officially classified as "severely handicapped." 25 The SGB IX then provides disadvantage compensations (Nachteilsausgleich) for severely handicapped people such as: special income tax deductions, the ability to retire two years earlier without deductions, or parking lots for wheelchair users. Effectively, all WDP beneficiaries are eligible for these benefits without any loss of WDP benefits before retirement since WDP is not means tested. ${ }^{26}$

In fact, almost one million people who are officially classified as severely handicapped work full time in Germany (Bundesagentur für Arbeit 2014). This outcome may be related, at least partly, to a quota system. It mandates employers with more than 19 full-time employees to employ at least $5 \%$ severely handicapped employees. Employers not complying with the quota must pay a monthly penalty (Ausgleichsabgabe) of $€ 290$ per unoccupied workplace. This effectively means that a small business with 20 full-time employees has to hire one severely handicapped worker or pay an annual penalty of $\$ 4500$. Lalive et al. 2013, using data from Austria, which has a similar quota system, show that it significantly increases the employment of handicapped people. ${ }^{27}$

\section{What can we take from these experiences?}

For policy makers, discussions of reforming disability benefit programs are accompanied by the knowledge that, even when not generous, disability benefits are essential income

\footnotetext{
${ }_{24}$ Before 2001, this was the Schwerbehindertengesetz.

${ }_{25}$ People with handicap ratings from 30 to $50 \%$ who have difficulty finding a job can apply for the workplace quota system described below.

26 Aarts et al. (1998) and Börsch-Supan and Jürges (2012) discuss pathways from early retirement to full retirement in the German system. Börsch-Supan and Jürges (2012) focus exclusively on Germany and provide a detailed discussion of its pathways to retirement. Unlike the WDP, Nachteilsausgleich offers those defined as severely handicapped a pathway to retirement two years earlier than non-handicapped people without actuarial penalty. In the context of our three tier system we view this option as a tier 1 benefit equal to the deductions that are typically applied in case of early retirement, i. e. $7.2 \%$ of the last wage.

27 Unlike for other countries, there is a notable absence of research on the German disability system and in particular the behavioral effects of policy choices.
} 
for many recipients. This is particularly true in the United States, where other components of the social safety net are weaker or less available. However, as the reform experiences in Germany, the Netherlands, and Sweden demonstrate, the dependence of workers with disabilities on cash transfers is not an irreversible state. Indeed, the reforms in these three countries point to considerable potential to keep workers with disabilties employed, either eliminating or delaying their movement onto the long-term disability rolls. On balance, these reform outcomes suggest that prowork policies can both reduce disability recipiency rates and increase employment among those with disabilities.

Another concern is that programs like disability insurance are especially important in economic downturns where individuals with limited work capacity are not only more likely to be laid off but less likely to find a new job. Past experience of EU countries, especially Germany and The Netherlands, which intentionally or unintentionally used this logic to turn their long-term disability programs into more general unemployment programs, suggests that this can be a very expensive and ultimately ineffective policy decision. Indeed, many EU nations continue to struggle to regain control over their disability systems which, for many decades, have been used as long-term unemployment insurance programs. A key message from the EU experience is that explicitly divorcing long-term "unemployability" insurance from disability insurance is critical to effectively targeting resources towards both populations.

Together the experiences of other nations suggest that it is possible to balance the competing goals of providing social insurance against adverse health shocks during working-age and maximizing the work effort of all working-age adults with and without disabilities. Past disability policies in both the United States and EU countries have focused more on the former than the latter, resulting in rapid growth in disability transfer populations that outpaced growth in the economy. Efforts to shift to more pro-work policies over the last decade in Europe suggest that fundamental disability reforms, if done well, can lower projected long-term costs for taxpayers, make the job of disability administrators less difficult, and importantly, improve the short- and long-run opportunities of people with disabilities.

Acknowledgements Burkhauser received partial funding for his work on this paper from the Rehabilitation Research and Training Center on Disability Statistics and Demographics at Hunter College, which is funded by the National Institute on Disability and Rehabilitation Research (NIDRR, Federal Award \# H133B120006). The contents of this paper do not necessarily represent the policy of NIDRR and readers should not assume endorsement by the Federal Government (Edgar, 75.620 (b)) or the Federal Reserve Bank of San Francisco or the Federal Reserve Board of Governors. We thank Jan Maarten van Sonsbeek for data on the Netherlands, Mårten Palme and Lisa Laun for data on Sweden, and Dr. Lueg as well as Ms. Kühnapfel from the German Insurance Association (Gesamtverband der Deutschen Ver- sicherungswirtschaft) for their data on private disability insurance policies and other background information on Germany. We also thank Benjamin Bradshaw, Aline Passlack, and Catherine van der List for excellent research assistance.

Conflict of interest R.V. Burkhauser, M.C. Daly and N.R. Ziebarth state that they have no competing interest.

Open Access This article is distributed under the terms of the Creative Commons Attribution 4.0 International License (http:// creativecommons.org/licenses/by/4.0/), which permits unrestricted use, distribution, and reproduction in any medium, provided you give appropriate credit to the original author(s) and the source, provide a link to the Creative Commons license, and indicate if changes were made.

\section{Appendix}

\section{Data description and sources}

Table 3 Summary of DI Data Availability across Countries

\begin{tabular}{lllll}
\hline Data Description & \multicolumn{5}{l}{} \\
\hline- & Netherlands & Sweden & United States & Germany \\
Initial Year & 1970 & 1970 & 1970 & 1970 \\
Final Year & 2009 & 2009 & 2011 & 2011 \\
Missing Years & $(-)$ & 1984 & 1981 & 1978 \\
$\begin{array}{l}\text { Age Range } \\
\begin{array}{l}\text { of Working } \\
\text { Population }\end{array}\end{array}$ & $15-65$ & $16-64$ & $16-64$ & $15-65$ \\
\hline
\end{tabular}

\section{Data sources}

Germany Deutsche Rentenversicherung (2014) on absolute number of WDP beneficiaries ("Renten wegen verminderter Erwerbsfähigkeit insgesamt"). Statistik der Deutschen Rentenversicherung (2014): "Rentenversicherung in Zeitreihen 2014", http://forschung.deutscherentenversicherung.de, and upon request.

Statistisches Bundesamt (2014) on population between 15 and 65 , unemployment rates, and people out of the labor force. https://www-genesis.destatis.de.

Netherlands Historical population data are from Statistics Netherlands. http://www.cbs.nl/en-GB/menu/home/ default.htm

Disability insurance caseloads data are from the Institute of Employee Benefit Schemes, courtesy of Jan Maarten van Sonsbeek.

Sweden Historical population estimates are from Statistics Sweden. http://scb.se 
Disability Insurance prevalence data are from the Social Insurance Agency yearbooks, courtesy of Lisa Laun and Marten Palme.

United States Historical population estimates are from the Census Bureau's Annual Estimates of Resident Population. http://www.census.gov

SSDI caseloads and covered workers data are from the Annual Statistical Supplement to the Social Security Bulletin. http://www.ssa.gov/policy/docs/statcomps/ supplement/

\section{References}

Aarts, L.J.M., Burkhauser, R.V., de Jong, P.R.: Convergence: a comparison of European and United States disability policy. In: Thomason, T., Burton, J., Hyatt, D. (eds.) New approaches to disability in the work place, pp. 299-338. IRRA Research, University of Southampton, Southampton (1998)

Andrén, D.: Sickness-related absenteeism and economic incentives in Sweden: a history of reforms, CESifo DICE Report, 1(3), 54-60, (2003)

Andrén, D.: Does part-time sick leave help individuals with mental disorders recover lost work capacity? J Occup Rehabil 24(2), 344-360 (2014)

Association of German Insurers (DGV): Statistical yearbooks of German insurance (2015). http://www.en.gdv.de/2014/11/propertycasualty-insurance-with-record-claims-expenditure/, accessed May 13, 2015

Autor, D.H., Duggan, M.G.: The rise in disability recipiency and the decline in unemployment. Q J Econ 118(1), 157-205 (2003)

Autor, D.H., Duggan, M.G.: The growth in the social security disability rolls: a fiscal crisis unfolding. J Econ Perspect 20, 71-96 (2006)

Autor, D.H., Duggan, M.G.: Supporting work: a proposal for modernizing the U.S. disability insurance system. The Hamilton Project and Center for American Progress, Washington, D.C. (2010)

Autor, D.H., Katz, L.F., Kearney, M.S.: Trends in US wage inequality: revising the revisionists. Rev Econ Stat 90(2), 300-323 (2008)

Autor, D.H., Duggan, M., Gruber, J.: Moral hazard and claims deterrence in private disability insurance. Appl Econ 6(4), 110-141 (2014)

Berkowitz, E.D., Burkhauser, R.V.: A United States perspective on disability programs. In: Aarts, L.J.M., Burkhauser, R.V., de Jong, P.R. (eds.) Curing the Dutch disease: an international perspective on disability policy reform, pp. 71-92. Ashgate, Aldershot (1996)

Black, D., Daniel, K., Sanders, S.: The impact of economic conditions on participation in disability programs: evidence from the coal boom and bust. Am Econ Rev 92, 27-50 (2002)

Borghans, L., Gielen, A.C., Luttmer, E.F.P.: Social support substitution and the earnings rebound: evidence from a regression discontinuity in disability insurance reform. Am Econ J Econ Policy 6(4), 34-70 (2014)

Börsch-Supan, A., Jürges, H.: Disability, pension reform, and early retirement in Germany, NBER chapters. In: Wise, D.A. (ed.) Social security programs and retirement around the world: historical trends in mortality and health, employment, and disability insurance participation, pp. 277-300. (2012)

Börsch-Supan, A., Roth, H.: Work disability and health over the life course. In: Börsch-Supan, A., Brandt, M., Hank, K., Schröder, M. (eds.) The individual and the welfare state, pp. 215-224. Springer, Berlin Heidelberg (2011)

Bound, John \& Burkhauser, Richard V.: "Economic analysis of transfer programs targeted on people with disabilities". Handbook of
Labor Economics. In: Ashenfelter, O. \& Card, D. (eds.) Handbook of Labor Economics, edition 1, volume 3, chapter 51, pp 3417-3528. Elsevier (1999)

Bundesagentur für Arbeit: Arbeitsmarket in Zahlen: Beschäftigungsstatistik, Schwerbehinderte Menschen in Beschäftigung (Anzeigeverfahren SGB IX) Deutschland 2012 (2014). https:// statistik.arbeitsagentur.de/, accessed Jan 11, 2015

Bundesministerium für Arbeit und Soziales (BMAS): Versorgungsmedizin-Verordnung (2009). http://www.bmas. de/DE/Service/Publikationen/k710-anhaltspunkte-fuer-dieaerztliche-gutachtertaetigkeit.html, accessed Jan 11, 2015

Bundesministerium für Arbeit und Soziales (BMAS): Rentenversicherungsbericht 2014 (2014). www.bmas.de, accessed Jan 11, 2015

Burkhauser, R.V.: Lessons from the West German approach to disability policy. In: Weaver, C.L. (ed.) Disability and work: incentives, rights and opportunities, pp. 83-87. American Enterprise Institute Press, Washington, DC (1991)

Burkhauser, R.V., Daly, M.C.: The economic consequences of disability: a comparison of german and american people with disabilities. J Disabil Policy Stud 5(1), 25-52 (1994)

Burkhauser, R.V., Daly, M.C.: The declining work and welfare of people with disabilities: what went wrong and a strategy for change. AEI Press, Washington, D.C. (2011)

Burkhauser, R.V., Daly, M.C.: Social security disability insurance: time for fundamental change. J Policy Anal Manag 31(2), 454-461 (2012)

Burkhauser, R.V., Petri, H.: United States disability policy in a time of economic crisis: a comparison with sweden and the federal republic of Germany. Milbank Q 67(2), 166-194 (1989)

Burkhauser, R.V., Schroeder, M.: A method for comparing the economic outcomes of the working-age population with disabilities in Germany and the United States. Schmoller Jahrb J Appl Soc Sci Stud 127(2), 227-258 (2007)

Burkhauser, R.V., Daly, M.C., McVicar, D., Wilkens, R.: Disability benefit growth and disability reform in the US: lessons from other OECD nations. IZA J Labor Policy 3, 4 (2014)

Burkhauser, R.V., M.C. Daly, and B.T. Lucking: Is Australia one recession away from a disability blowout? Lessons from other Organisations for Economic Co-operation and Development countries. Australian Economic Review 46 (3), 357-368 (2013)

Chen, S., van der Klaauw, W.: The work disincentive effects of the disability insurance program in the 1990s. J Econom 142(2), 757-784 (2008)

Daly, M., Lucking, B., Schwabish, J.: Explaining the rapid growth in social security disability insurance rolls. Federal Reserve Bank of San Francisco, San Francisco (2013)

Deutsche Rentenversicherung (DRV): Rentenversicherung in Zeitreihen 2011, Kapitel 15, Chronik (2012). http://forschung.deutscherentenversicherung.de/, accessed Jan 11, 2015

Deutsche Rentenversicherung: Rentenversicherung in Zahlen 2014 (2014a). http://www.deutsche-rentenversicherung.de/cae/servlet/ contentblob/238692/publicationFile/61815/01_rv_in_zahlen_ 2013.pdf, accessed Jan 11, 2015

Deutsche Rentenversicherung: Erwerbsminderungsrente: Das Netz für alle Fälle, 9th edition (2014b). http://www.deutscherentenversicherung.de/Allgemein/de/Inhalt/5_Services/ 03_broschueren_und_mehr/01_broschueren/01_national/ erwerbsminderungsrente_das_netz_fuer_alle_faelle.html, accessed Jan 11, 2015

Deutsche Rentenversicherung: Statistik der Deutschen Rentenversicherung, Rentenbestand am 31.12.2013, Band 197 (2014c). http://www.deutsche-rentenversicherung.de/, accessed Jan 11, 2015

Duggan, M., Imberman, S.: Why are the disability rolls skyrocketing? The contribution of population characteristics, economic conditions, and program generosity. In: Cutler, D., Wise, D. (eds.) Health at older ages: the causes and consequences of de- 
clining disability among the elderly. University of Chicago Press, Chicago (2009)

Eichhorst, W., Grienberger-Zingerle, M., Konle-Seidl, R.: Activation policies in Germany: from status protection to basic income support. In: Konle-Seidl, R., Eichhorst, W., Kaufmann, O. (eds.) Bringing the jobless into work? pp. 17-67. (2008)

Franke, Bornberg: Berufsunfähigkeitsversicherung verliert an Bedeutung (2014). http://www.franke-bornberg.de/uploads/media/ Berufsunfaehigkeits-Versicherungs_verliert_an_Bedeutung.pdf, accessed Jan 12, 2015

Goss, S.: "Testimony by Steve Goss, Chief Actuary, Social Security Administration before the House Committee on Ways and Means, Subcommittee on Social Security," March 14, 2013 (2013)

Hartman, L.: Swedish Policies for the Disabled: What Do We Know About the Effects? Mimeo, prepared for the "Labour Activation in a Time of High Unemployment" November 13-15, 2011, hosted jointly by the University of Maryland and the OECD (2011). http://umdcipe.org/conferences/LaborActivationParis/ Papers/Laura\%20Heartmans\%20draft\%20paper_11_1108.pdf, accessed Oct 18, 2012

Høgelund, J., Holm, A., McIntosh, J.: Does graded return-to-work improve sick-listed workers' chance of returning to regular working hours? J Health Econ 29(1), 158-169 (2010)

Jönsson, L., Palme, M., Svensson, I.: Disability insurance, population health and employment in Sweden (no. w17054). National Bureau of Economic Research, Cambrige (2011)

Jürges, H.: True health vs. response styles: exploring cross-country differences in self-reported health. Health Econ 16(2), 163-178 (2007)

Kemptner, D.: Erwerbsminderung als Armutsrisiko. DIW Roundup: Politik im Fokus, vol. 8. DIW, German Institute for Economic Research, Berlin (2014)

Koning, P., Lindeboom, M.: The rise and fall of disability insurance enrollment in the Netherlands. J Econ Perspect 29(2), 151-172 (2015)

Konle-Seidl, R.: Unemployment assistance in Germany. Int Labor Brief 10(9), 13 (2012)

Krause, P., Ehrlich, U., Möhring, K.: Erwerbsminderungsrentner: sinkende Leistungen und wachsende Einkommensunterschiede im Alter. DIW Wochenber 80(24), 3-9 (2013)

Lalive, R., Wuellrich, J.-P., Zweimüller, J.: Do financial incentives affect firms' demand for disabled workers? J Eur Econ Assoc 11(1), 25-58 (2013)

Larsson, L.: Sick of being unemployed? Interactions between unemployment and sickness insurance in Sweden. Scand J Econ, 108(1), 97-113 ( 2006)

Lewin-VHI: Labor market conditions, socioeconomic factors and the growth of applications and awards for SSDI and SSI disability benefits. Final report. The Office of the Assistant Secretary for Planning and Evaluation, U.S. Department of Health and Human Services and the Social Security Administration, Washington DC (1995)

Liebman, J.B.: Understanding the increase in disability insurance benefits receipt in the United States. J Econ Perspect 29(2), 123-150 (2015)

Maestas, N., Mullen, K.J., Strand, A.: Does disability insurance receipt discourage work? Using examiner assignment to estimate causal effects of SSDI receipt. Am Econ Rev 103(5), 1797-1829 (2013)

Markussen, S., Mykletun, A., Røed, K.: The case for Presenteeism - evidence from Norway's sickness insurance program. J Public Econ 96(11), 959-972 (2012)

McGee, D.L., Liao, Y., Cao, G., Cooper, R.S.: Self-reported health status and mortality in a multiethnic US cohort. Am. J. Epidemiol. 149, 41-46 (1999)

Moore, T.J.: The employment effects of terminating disability benefits. J Public Econ 124(C), 30-43 (2015)

Mullen, K., Staubli, S.: Disability benefit generosity and labor force withdrawal. NBER Working Paper, vol. 22419. (2016)
National Audit Office: Support to incapacity benefits claimants through pathways to work. National Audit Office, London (2010)

Organization for Economic Co-operation and Development (OECD): Transforming disability into ability (2003). http://www.keepeek. com/Digital-Asset-Management/oecd/social-issues-migrationhealth/transforming-disability-into-ability_9789264158245-en\# page 1, accessed Jun 16, 2016

Organization for Economic Co-operation and Development (OECD): Sickness, disability and work: keeping on track in the economic downturn - background paper (2009). www.oecd.org/dataoecd/ 42/15/42699911.pdf, accessed May 15, 2013

Organization for Economic Co-operation and Development (OECD): Sickness, disability and work: breaking the barriers: a synthesis of findings across OECD countries. OECD Publishing, Paris (2010)

Pattison, D., Waldron, H.: Growth in new disabled-worker Entitlements, 1970-2008. Soc Secur Bull 73(4), 25 (2013)

Prinz, C., William, T.: Sickness and disability benefit programmes: what is driving policy convergence. Int Soc Secur Rev Spec Issue Policy Learn Soc Prot 62, 41-61 (2009)

Rebick, M.: Social security and older workers' labor market responsiveness: the United States, Japan and Sweden. In: Blank, R. (ed.) Social protection versus economic flexibility: is there a trade-off?. University of Chicago Press, Chicago (1994)

Reno, V.P., Ekman, L.D.: Disability insurance is part of the solution, not a cause of work disability: response to Burkhauser and Daly. J Policy Anal Manag 31, 471-474 (2012)

Riphahn, R.T.: Disability retirement and unemployment - substitute pathways for labour force exit? An empirical test for the case of Germany. Appl Econ 29(5), 551-561 (1997)

Riphahn, R.T.: Disability retirement among German men in the 1980s. Ind Labor Relat Rev 52(4), 628-647 (1999)

Robert Koch Institut (RKI): Gesundheitsbedingte Frühberentung, Gesundheitsbericht-erstattung des Bundes, Heft 30, Statistisches Bundesamt (2006). http://www.rki.de/DE/ Content/Gesundheitsmonitoring/Gesundheitsberichterstattung/ Themenhefte/fruehberentung_inhalt.html, accessed Jan 11, 2015

Rupp, K., Stapleton, D.: Determinants of the growth in the social security administration's disability programs: an overview. Soc Secur Bull 58, 43-70 (1995)

Social Security Administration: How you earn credits, Washington, D.C (2013a). http://www.ssa.gov/pubs/EN-05-10072.pdf, accessed May 15, 2013

Social Security Administration: The 2013 Annual Report of the Board of Trustees of the Federal Old-Age and Survivors Insurance and Federal Disability Insurance Trust Funds, Washington, D.C (2013b). http://www.ssa.gov/oact/tr/2013/tr2013.pdf, accessed May 15, 2013

Soest, A. van, Tatiana, A., Kapteyn, A., Smith, J.P.: Self-reported disability and reference groups,NBER chapters. In: Investigations in the economics of aging, pp. 237-264. National Bureau of Economic Research, Cambrige (2011)

Sonsbeek, J.M. van, Gradus, R.: Estimating the effects of recent disability reforms in the Netherlands. Tinbergen Institute Discussion Papers 11-121/3. Tinbergen Institute, Amsterdam (2011)

Stapleton, D., Coleman, K., Dietrich, K., Livermore, G.: Empirical analyses of DI and SSI application and award growth. In: Rupp, K., Stapleton, D. (eds.) Growth in disability benefits, pp. 31-92. W.E. Upjohn Institute for Employment Research, Michigan (1998)

Statistika: Anteil der Berufstaetigen in Deutschland, die eine Berufsunfaehigkeits-versicherung abgeschlossen haben (2014). http://de.statista.com/statistik/daten/studie/237869/umfrage/ umfrage-zum-abschluss-einer-berufsunfaehigkeitsversicherungnach-geschlecht/, accessed January 25, 2015

Statistisches Bundesamt: Statistisches Jahrbuch - Ältere Ausgaben, Bevölkerungszahlen der Altersgruppen 15 bis 65 (2014). https:// www.destatis.de/DE/Publikationen/StatistischesJahrbuch/Statisti 
schesJahrbuch_AeltereAusgaben.html, accessed January 25, 2015

Staubli, S.: The impact of stricter criteria for disability insurance on labor force participation. J Public Econ 95(9-10), 1223-1235 (2011)

Wachter, T. von, Song, J., Manchester, J.: Trends in employment and earnings of allowed and rejected applicants to the social security disability insurance program. Am Econ Rev 101(7), 3308-3329 (2011)

World Health Organization (WHO): International Classification of Disability, Health and Functioning. WHO, Geneva (2001)

Ziebarth, N.R.: Langzeitkranke verlieren durch Kürzung des Krankengeldes fünf Milliarden Euro. DIW Wochenber 76(20), 326-332 (2009)
Ziebarth, N.R.: Measurement of health, health inequality, and reporting heterogeneity. Soc Sci Med 71(1), 116-124 (2010a)

Ziebarth, N.R.: Estimating price elasticities of convalescent care programmes. Econ J 120(545), 816-844 (2010b)

Ziebarth, N.R.: Long-term absenteeism and moral hazard - evidence from a natural experiment. Labour Econ 42, 277-292 (2013)

Ziebarth, N.R.: Assessing the effectiveness of health care cost containment measures: evidence from the market for rehabilitation care. Int J Health Care Finance Econ 14(1), 41-67 (2014)

Ziebarth, N.R., Karlsson, M.: A natural experiment on sick pay cuts, sickness absence, and labor costs. J Public Econ 94(11-12), 1108-1122 (2010)

Ziebarth, N.R., Karlsson, M.: The Effects of Expanding the Generosity of the Statutory Sickness Absence Insurance. J Appl Econom 29(2), 208-230 (2014) 